\title{
INTELLIGENCE, TALENT AND GENIUS
}

\author{
Araujo Filho W.D ${ }^{* 1} 凹$, Silva F.M 2 \\ ${ }^{*}$ State University of Bahia-Department of Exact and Earth Sciences-Physics Collegiate, Brazil \\ 2 State University of Southwest Bahia-Department of Exact and Technological Sciences (UESB), \\ Brazil
}

DOI: https://doi.org/10.29121/granthaalayah.v8.i7.2020.442

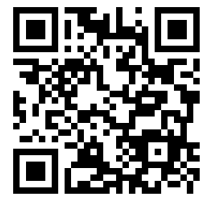

Article Type: Research Article

Article Citation: Araujo Filho W.D, and Silva F.M. (2020).

INTELLIGENCE, TALENT AND

GENIUS. International Journal of

Research -GRANTHAALAYAH, 8(7),

313-317.

https://doi.org/10.29121/granthaa

layah.v8.i7.2020.442

Received Date: 15 June 2020

Accepted Date: 31 July

2020

Keywords:

Imagination

Intelligence

Talent

Genius

\begin{abstract}
In this paper discusses in an open manner the differences between intelligence, talent and genius. These three human capacities are often informally confused, but they have their own distinct characteristics. Talent is associated with the ability to execute intellectual and practical actions with an enormous degree of perfection. In this case, theory and practice become inseparable in the development of these actions. Genius permeates talent and intelligence, and has a differentiated ingredient, called imagination, which makes the holder of this intellectual capacity look further, crossing steps in the creation process.
\end{abstract}

\section{INTRODUCTION}

In this article we discuss some concepts, which by their nature are controversial, related to human creativity, which permeate several domains of human knowledge. In particular, we will deal with the concepts of intelligence, talent and genius, referring to studies in psychology, biology and the history and philosophy of science, without losing sight of the contribution of other sciences in the development of this theme.

\subsection{HUMAN INTELLIGENCE VERSUS TALENT}

According to science, the emergence of intelligence in the human race was a fortuitous event, very rare, and whose possibility of occurring again in a natural environment, or on another planet, is insignificant, being a phenomenon unlikely to repeat itself. Since man stopped living in a nomadic way, and started to live in groups, he started to develop practical skills related to agriculture, making utensils and weapons, as well as to develop intellectual skills related to sky observation, in order to predict the climatic inclement weather (droughts, rainy

(C) 2020 The Author(s). This is an open access article distributed under the terms of the Creative Commons Attribution License, which permits unrestricted use, distribution, and reproduction in any medium, provided the original author and source are credited. 
periods and intense cold). In addition, he began to develop interpersonal attitudes resulting in the phenomenon of socialization and, in the emergence of a more structured family cell [1].

The emergence of commerce enabled the exchange of experiences between individuals, making them more critical, thus leading to a faster intellectual evolution and linked to their survival needs. In addition, with the advent of written language, man began to express his thoughts in a more pragmatic way, making them more objective, developing the practical capacity for problem solving, verbal aptitude, reasoning, thinking logically, and mastery broad spectrum of information.

The confluence of all these capacities led man to take the lead in face of the challenges imposed by the environment in which he was inserted. With his intelligence he became an agent that transformed the world.

Currently, human intelligence is increasingly discussed. People are said to be more intelligent than others. There are those who claim that women are more intelligent than men, due to their greater sensitivity, in addition to saving information more easily in their memory [2].

In this tuning fork, some questions come to the fore, namely: Why among so many living beings, only the human being managed to conquer intelligence? How did this happen? Why does homo erectus have intelligence so absent in other animals?

The theory of evolution is attentive to the possibility of nature producing intelligent beings by known evolutionary processes. Even so, it is very difficult to understand why 30 million living species today, and about 50 billion other living or disappearing species, and only the human species has developed superior intelligence, multiplying its ability to survive. This leads us to think of supernatural causes, or of pure probabilistic chance.

Studies developed at Harvard University in the United States, point out that intelligence is nothing more than the knowledge received by man, that is, reasoning, which is used by him through memory. The reasoning is, therefore, the speed with which the human being apprehends knowledge, whereas memory is the interval of time that knowledge can be kept in the human mind [3], [4], [5].

The word intelligence is usually related to the word talent. It is common to say that if a person is intelligent, he has a great talent. In reality, the link is not always true.

Talent is a word that, at first, is very direct, and few people would be in doubt as to its meaning. We can mention two important aspects of interpreting the expression. The first, refers to the use of talent to describe people who are better at what they do, who have a differential, and stand out in relation to other people. The second is more linked to the fact that all people are talented, and what talent would then be to value what each one has the best. Thus, we run into a problem of interpretation. One point of view is totally different from the other, yet we cannot say clearly what is right or wrong.

The biggest problem is that one interpretation is totally different from the other, but we cannot say which one is right, or wrong. It is tempting to believe in the idea of people with unparalleled talents, capable of solving problems in a magical and instantaneous way. This form of interpretation induces the existence of extremely talented people, and therefore more capable than others. It can be said that talent is related to the individual's ability to perform intellectual actions with a high content of perfection. The talented individual dominates what he sets out to do.

According to psychology Stachewski [6], every human being has some talent. She points out, four main capabilities:

- Knowledge or knowledge: this domain has to do with everything the person has learned through formal education, at school, undergraduate, graduate or training courses. It is theoretical knowledge, which can be identified through the curriculum. It is related to the teaching and learning process.

- Ability or know-how: it is known, however, that it is no use just to know, you have to know how to do it. This is where this domain of talent comes in, the ability to apply theoretical knowledge in practice.

- Judging or knowing how to analyze: this talent goes a little further, and is related to the ability to be able to analyze the knowledge and skills of others - or even machines - that perform important functions.

- Attitude or making it happen: in other words, this domain can be understood as proactivity. It is that person who knows, knows how to do it, can analyze processes and has the initiative to put all this into practice.

Talented people incorporate all of these skills, and are generally successful professionally, which is not the case with most so-called "normal" people. On the other hand, although all human beings have intelligence, they are not always gifted with talent. 


\subsection{TALENT AND GENIUS}

As previously discussed, a person's talent is associated with his ability to carry out intellectual and practical actions with an enormous degree of perfection. In this case, theory and practice become inseparable in the development of these actions.

We are going to introduce another word that is sometimes confused with intelligence and talent: genius.

According to WEINER (2016), history is the uncalculated sum of one million everyday moments. What differentiates genius from a great talent or from an intelligent person? Why are there people who are gifted with extraordinary talent?

For the author, paradise is antagonistic to genius. Paradise makes no demands, and the creative genius emerges by meeting demands in new, challenging and imaginative ways [7], [8]. Genius minds have a creativity that reaches levels that most people may never be able to. They are capable of making non-linear and unpredictable intellectual leaps, which makes them different. When this happens, technical and intellectual procedures are spared which would take days or perhaps years to be implemented, which can be called the "leap of genius" [9]. In reality, the mind of the genius works together with the rationality and subtlety of the imponderable [10], [11], [12].

Throughout history, brilliant minds have stood out, among them we will mention those of Leonardo da Vinci, Galileo Galilei, Isaac Newton and Albert Einstein (Figure 1).
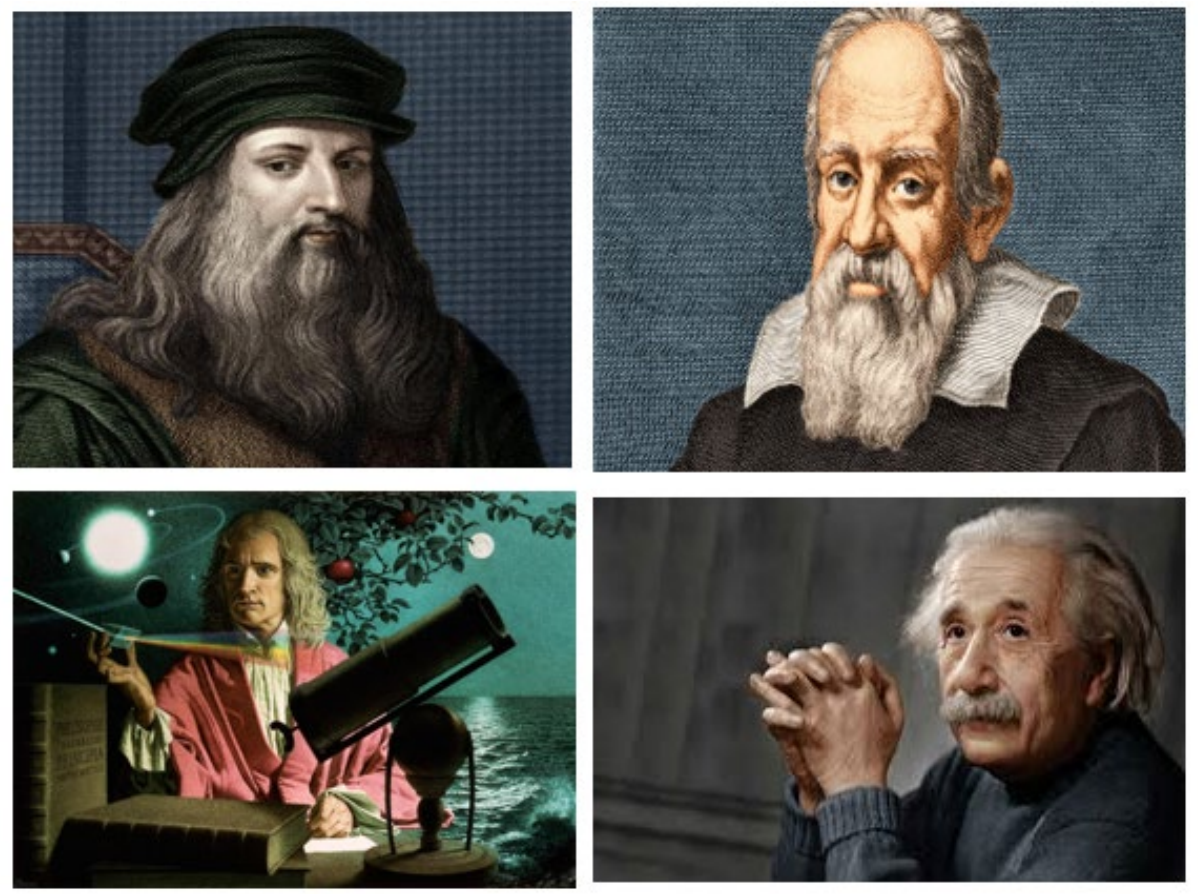

Figure 1: Personalities considered brilliant who were part of the history of human development. Top left Leonardo da Vinci, right Galilean Galilei, bottom left Isaac Newton and right Albert Einstein.

Source: Wikipedia images.

These genius minds were far beyond their time, managing to see much further than most of their peers from the time when each lived.

Leonardo da Vinci was a visionary. He dominated almost all areas of knowledge such as Physics, Mathematics, Philosophy, Medicine, Engineering, Music, and the arts in general. His works are studied to this day, and many of them are very current.

Galileo Galilei was another visionary, he did not invent the spyglass, but according to history he was the first to point it towards the sky in a systematic way. In doing so Galileo changed the paradigm of Astronomy. He discovered that the universe did not have static and immutable characteristics, but rather, it was a ball consisting of millions of millions of stars, and celestial bodies. Galileo is a genius because of the power to see beyond his time. Like Da Vinci, he had mastery of almost every area of knowledge, hence the genius of his mind. 
Isaac Newton, also considered one of the greatest geniuses of all time, had an impressive mental capacity, before the age of 25 he had already prepared one of the greatest works of all time, Philosophiae Naturalis Principia Mathematica, published in 1687.With this work Newton unified terrestrial and celestial physics, in addition to developing a revolutionary mathematical tool, the Differential and Integral Calculus.

Albert Einstein is considered by the majority of the scientific community to be the greatest genius that ever existed in humanity. In 1999 he was elected by 100 renowned physicists as the most memorable physicist of all time. He carried out works in the field of theoretical physics, developing the theory of general relativity alongside quantum mechanics. Although he is known for the famous equation that links matter, energy and the speed of light $(\mathrm{E}=\mathrm{mc} 2)$, he received the Nobel Prize in Physics in 1921 for formulating the theory of the Photoelectric Effect, which was fundamental for the establishment of Quantum Mechanics.

It is interesting to state that the four personalities mentioned above had very similar behaviours in relation to how to interact with the real world. The intelligence associated with the ability to put ideas into practice, in addition to a lot of imagination, had made them different from their peers [12].

Genius is the result of a process that encompasses intelligence, talent, motivation, discipline, creativity, intuition and imagination. Furthermore, geniuses are far less nerdy than you think. How did Einstein conceive the theory of relativity? What made Galileo aim the telescope at the sky? For Dean Keith Simonton, professor of psychology at the University of California, a common thread between them is precisely versatility. Einstein was a well-known sleeper, but he found time to play Bach and Mozart on the violin. According to Simonton, Galileo probably identified Jupiter's satellites because he liked to paint: the drawings of the moon made by him with an impressive wealth of details attest to his artistic aptitude [13], [14].

The versatility of their personalities played a very important role in their work as a whole. Doing science for them was a moment of full control of the intellect, where intuition and imagination played a decisive role in the development of their work [12], [15].

\section{CONCLUSION}

Intelligence is a factor present in all human beings; whose acquisition occurred at a certain moment in the evolution of the human race (species). Talent, in turn, is related to the ability (aptitude) that certain people have to develop certain specific skills. In other words, a person may have exceptional talent, but comparing him with a genius is another story. In turn, genius denotes the individual's ability to see further, almost always leading to the burning of stages in the creation process

\section{SOURCES OF FUNDING}

This research received no specific grant from any funding agency in the public, commercial, or not-for-profit sectors.

\section{CONFLICT OF INTEREST}

The author have declared that no competing interests exist.

\section{ACKNOWLEDGMENT}

None.

\section{REFERENCES}

[1] HARARI, Y. N. Sapiens: A Brief History of Humankind. Harper Perennial, 1976.

[2] Sternberg R. J. et al. Personality and Intelligence. Cambridge University Press, 1994.

[3] Neubauer, A. C.; Martskvishvili, K. Creativity and intelligence: A link to different levels of human needs hierarchy? Heliyon, v. 4, n. 5, p. e00623, 2018. 
[4] Mayr Ernst. The Growth of Biological Thought: Diversity, Evolution, and Inheritance. Harvard University Press, 1982.

[5] Karlberg. L. Os tipos de inteligência Humana. 2010. http://luisalessa.blogspot.com/2010/07/os-tipos-deinteligencia-humana.html

[6] STACHEWSKI, A.L. O que são talentos humanos - e por que conhecer os seus pode fazer a diferença, 2018. https://epocanegocios.globo.com/Vida/noticia/2018/10/o-que-sao-talentos-humanos-e-por-queconhecer-os-seus-pode-fazer-diferenca.html

[7] Weiner, E. Onde Nascem os Gênios. Publisher: Darkside Books Release Date: Tradução: Dalton Caldas. 2016. $352 \mathrm{p}$.

[8] Avillez. G. How to identify a Genius? http://lounge.obviousmag.org/esquina_do_obvio/2016/06/indicios-de-genialidade.html

[9] McEvoy, J; Zarate, O. Introducing Quantum Theory: A Graphic Guide. Icon Books Ltd, 5 de jun. de 2014 - 176 pages.

[10] Kercya, K. Onde nascem os gênios: quando a genialidade é humana. Resenhas. 2017

[11] Johanes Hessen. Teoria del conocimiento / Theory of Knowledge. Grupo Editorial Tomo, 2008 - 228 paginas.

[12] Araujo Filho, W. D. The genesis of Galilean thought. Editora Livraria da Física. São Paulo. 2008. 120 p.

[13] Ken Greider. Invitation to Physics. Harcourt Brace Jovanovich, 1973.

[14] Simonton, D. K. A origem do gênio: Perspectivas Darwinianas sobre a criatividade: Perspectivas Darwinianas sobre a criatividade. Tradução: Carlos Humberto Pimentel D. da Fonseca. Record; Edição: 12002.

[15] Geymonat, L. Galileu Galilei. Editora Nova Fronteira. 1997. 